\title{
Pulmonary oedema in paraquat poisoning
}

\author{
A. J.S. G A R D I N E R
}

Aberdeen Royal Infirmary, Foresterhill, Aberdeen AB9 2ZB

\begin{abstract}
This is the case report of a 47-year-old man who swallowed a powerful commercial herbicide containing paraquat. He developed oral, oesophageal, renal, and hepatic damage and, at an earlier stage than is usual, severe pulmonary changes from which he made a satisfactory recovery. The disordered pulmonary function and production of pulmonary oedema fluid in this patient are attributed to interference with surfactant activity in the lung.
\end{abstract}

The progression of the pathological effects in the lungs is said to be relentless when clinical evidence of lung involvement is found in paraquat poisoning (Matthew, Logan, Woodruffe, and Heard, 1968). Survival from poisoning has been recorded several times, however (leading article, 1967 ; McKean, 1968 ; Kerr, Patel, Scott, and Tompsett, 1968; Oreopoulos and McEvoy, 1969 ; McDonagh and Martin, 1970), and therapy aimed at ridding the body of the poison has been described (Kerr et al., 1968). The progress of the following case shows that survival from paraquat poisoning may occur even though the lungs seem to have been severely injured.

\section{CASE REPORT}

At 3 p.m. on 3 August 1970 the patient, a 47-year-old chargehand with Aberdeen Corporation Links and Parks Department, swallowed a mouthful of an undiluted commercial herbicide, containing $9 \%$ paraquat and $9 \%$ diquat (trade name Gramoxone (I.C.I.)). The poison was swallowed after a packed lunch at mid-day. He maintained that he had spat out most of this single mouthful but was equally certain that he had swallowed some. He felt quite well the next day and went to work but that evening, some 34 hours after ingestion, he developed severe pain in the tongue and throat and excess salivation. He was referred by his doctor to the casualty outpatient department of the Aberdeen Royal Infirmary where, on examination, no abnormality was detected apart from painfullooking necrotic ulceration of the tongue and pharynx. On the advice of the Edinburgh Royal Infirmary Poisons Information Centre a forced diuresis was begun. This was started 44 hours after ingestion of the poison. The prediuresis urine specimen contained $0.05 \mathrm{mg}$ paraquat per $100 \mathrm{ml}$ of urine. Paraquat was present in the urine produced during forced diuresis in a concentration of $0.015 \mathrm{mg} / 100 \mathrm{ml}$. The urinary diquat levels were not measured. Forced diuresis was discontinued after 6 hours because of fine crepitations $\stackrel{c}{\check{\nu}}$ in the lungs although no evidence of fluid overload was found in the systemic circulation. Renal function, as assessed by urea, electrolyte, and acid-base measurements, was normal before the diuresis. During $\vec{\varphi}$ the period of forced diuresis 2.6 litres of urine were $N$ excreted.

On August 5 he developed diarrhoea and rigors although his temperature was not raised. He also complained of pain on swallowing and continuous burning retrosternal discomfort.

On August 6, after a sleepless night during which $\underset{\mathbb{Q}}{\mathbb{2}}$ he complained of increasing cough productive of bloodstained frothy sputum, he was transferred to a 윽 general medical unit at Aberdeen Royal Infirmary. In addition to the necrotic ulceration of the tongue and fauces he had tender submandibular adenopathy. His respiratory rate was increased at $30 /$ minute and fine crepitations were present over both lower lobes 응 and the right middle lobe. He was treated sympto- $\stackrel{\square}{x}$ matically for the pain arising from the mouth and oesophagus with analgesic lozenges and antacid gel. Such was the pain on swallowing that his fluid intake $\hat{\rho}$ was maintained by the intravenous route for the next 3 five days. On purely empirical grounds oral corti- 0 costeroids in the form of $20 \mathrm{mg}$ prednisone thrice $\supset$ daily were started and this high dose was tapered off $\frac{7}{0}$ after one week.

In addition to the pain arising from the lesions in $\bar{N}$ the mouth and oesophagus, he complained of breathlessness and continuous cough productive of large $N$ volumes of white, frothy, blood-tinged sputum sug- N gestive of pulmonary oedema fluid. The excessive $\sigma$ salivation, which was one of his first symptoms, did not persist beyond the third day. On August 8 and 90 he actually produced over 2 litres of sputum per $24 \mathbb{E}$ hours. The sputum volume gradually decreased but was still copious two weeks after ingestion of the poison (Table I). Fine crepitations persisted until the eleventh day after poisoning, and sonorous rhonchi $\frac{\mathbb{Q}}{\Omega}$ became evident during the second week when his $\mathbb{D}$ recovery was complicated by acute bronchitis. This was quickly controlled by ampicillin. Once the oral 
T A B LE I

\begin{tabular}{|c|c|c|c|c|c|c|c|c|c|c|c|c|c|c|c|}
\hline & \multicolumn{15}{|c|}{ Day after Ingestion } \\
\hline & 2 & 3 & 4 & 5 & 6 & 7 & 8 & 9 & 10 & 11 & 13 & 14 & 17 & 20 & 24 \\
\hline Date & $\begin{array}{c}5 \\
\text { Aug. }\end{array}$ & $\begin{array}{c}6 \\
\text { Aug. }\end{array}$ & $\begin{array}{c}7 \\
\text { Aug. }\end{array}$ & $\begin{array}{c}8 \\
\text { Aug. }\end{array}$ & $\begin{array}{c}9 \\
\text { Aug. }\end{array}$ & $\begin{array}{c}10 \\
\text { Aug. }\end{array}$ & $\begin{array}{c}11 \\
\text { Aug. }\end{array}$ & $\begin{array}{c}12 \\
\text { Aug. }\end{array}$ & $\begin{array}{c}13 \\
\text { Aug. }\end{array}$ & $\begin{array}{c}14 \\
\text { Aug. }\end{array}$ & $\begin{array}{c}16 \\
\text { Aug. }\end{array}$ & $\begin{array}{c}17 \\
\text { Aug. }\end{array}$ & $\begin{array}{c}20 \\
\text { Aug. }\end{array}$ & $\begin{array}{c}24 \\
\text { Aug. }\end{array}$ & $\begin{array}{c}28 \\
\text { Aug. }\end{array}$ \\
\hline Urea (mg \%) & 34 & 54 & & 80 & & 71 & & 79 & & 75 & & 66 & 60 & 43 & 48 \\
\hline $\begin{array}{l}\mathrm{Na}(\mathrm{mEq}) \\
\mathrm{K} \\
\mathrm{Cl} \\
\mathrm{HCO}_{3}\end{array}$ & $\begin{array}{l}132 \\
3 \cdot 4 \\
96 \\
25 \cdot 5\end{array}$ & $\begin{array}{c}131 \\
3.0 \\
92 \\
23.5\end{array}$ & & $\begin{array}{c}136 \\
2 \cdot 9 \\
99 \\
25 \cdot 5\end{array}$ & & $\begin{array}{c}140^{3 \cdot 8} \\
100^{39}\end{array}$ & & $\begin{array}{c}144 \\
4 \cdot 2 \\
101 \\
28 \cdot 5\end{array}$ & & $\begin{array}{c}145 \\
4 \cdot 2 \\
100 \\
34 \cdot 0\end{array}$ & & $\begin{array}{l}140 \\
3 \cdot 5 \\
99 \\
34 \cdot 5\end{array}$ & $\begin{array}{c}141 \\
4 \cdot 1 \\
98 \\
32\end{array}$ & $\begin{array}{c}141 \\
3 \cdot 8 \\
101 \\
32\end{array}$ & $\begin{array}{c}144 \\
4 \cdot 0 \\
102 \\
34\end{array}$ \\
\hline $\begin{array}{l}\text { Alkaline phosphatase } \\
\text { Bilirubin (mg \%) } \\
\text { Zinc sulphate } \\
\text { Thymol turbidity } \\
\text { SGPT (i.u.) }\end{array}$ & & \begin{tabular}{r|}
9 \\
$1 \cdot 6$ \\
$4 \cdot 0$ \\
$2 \cdot 0$ \\
150
\end{tabular} & & $\begin{array}{l}10 \\
1 \cdot 5 \\
4 \cdot 0 \\
1 \cdot 0 \\
90\end{array}$ & & $\begin{array}{l}7 \\
1 \cdot 5 \\
5 \cdot 0 \\
1 \cdot 0 \\
15\end{array}$ & & \begin{tabular}{r|}
7 \\
$0 \cdot 7$ \\
$6 \cdot 0$ \\
$2 \cdot 0$ \\
18
\end{tabular} & & $\begin{array}{c}9 \\
0 \cdot 9 \\
4 \cdot 0 \\
2 \cdot 0 \\
22\end{array}$ & & $\begin{array}{l}9 \\
0 \cdot 5 \\
4 \cdot 0 \\
2 \cdot 0 \\
15\end{array}$ & $\begin{array}{l}8 \\
0 \cdot 3 \\
4 \cdot 0 \\
3 \cdot 0 \\
14\end{array}$ & $\begin{array}{l}8 \\
0 \cdot 5 \\
5 \cdot 0 \\
2 \cdot 0 \\
7\end{array}$ & $\begin{array}{l}0.7 \\
2 \cdot 0 \\
1.0 \\
7\end{array}$ \\
\hline $\begin{array}{l}\text { 24-hr urine vol. } \\
\text { Specific gravity } \\
\text { pH } \\
\text { Protein } \\
\text { Blood } \\
\text { Sugar } \\
\text { Bilirubin } \\
\text { Excess urobilinogen } \\
\text { Paraquat } \\
\text { Microscopy }\end{array}$ & & $\begin{array}{c}1000+ \\
1008 \\
6 \\
1+ \\
2+ \\
\text { Trace } \\
\text { Nil } \\
\text { Nil } \\
\text { Nil } \\
\text { RBCs } \\
\text { Debris } \\
++ \\
\text { No } \\
\text { casts }\end{array}$ & 1800 & $\begin{array}{c}800 \\
1008 \\
6 \\
\text { Trace } \\
2+ \\
\text { Trace } \\
\text { Nil } \\
\text { Nil } \\
\text { Nil } \\
\text { RBCs } \\
\text { Debris } \\
++ \\
\text { No } \\
\text { casts }\end{array}$ & $\begin{array}{c}1100 \\
1016 \\
5 \\
\text { Trace } \\
\text { Trace } \\
\text { Nil } \\
\text { Nil } \\
\text { Nil } \\
\text { Nil } \\
\text { RBCs } \\
\text { Debris } \\
+\end{array}$ & $\begin{array}{c}1900 \\
1016 \\
5 \\
- \\
\overline{0} \cdot \overline{25} \% \\
= \\
- \\
\text { Debris } \\
+\end{array}$ & $\begin{array}{c}1750 \\
1012 \\
6 \\
- \\
0 \cdot 5 \% \\
\overline{1} \overline{\text { unit }} \\
- \\
\begin{array}{c}\text { Debris } \\
+\end{array}\end{array}$ & $\begin{array}{c}1750 \\
1018 \\
5 \\
\overline{-} \\
0.25 \% \\
\bar{E} \\
\text { n.a.d. }\end{array}$ & 1300 & $\begin{array}{c}1013 \\
6 \\
\overline{-} \\
\overline{25} \% \\
-\end{array}$ & $\begin{array}{c}1010 \\
- \\
= \\
= \\
= \\
\text { n.a.d. }\end{array}$ & & $\begin{array}{c}\text { Creatinine } \\
\text { Clear } \\
49 \mathrm{ml} / \mathrm{mm}\end{array}$ & & \\
\hline Sputum volume $(\mathrm{ml})$ & & 845 & 1500 & 2500 & 1740 & 500 & 280 & $?$ & 150 & & 175 & & $<100$ & $<50$ & 50 \\
\hline
\end{tabular}

T A B LE I I

\begin{tabular}{|c|c|c|c|c|c|}
\hline & & $\begin{array}{c}\text { Predicted } \\
\text { Normal }\end{array}$ & 4 Aug. & 5 Aug. & 24 Aug \\
\hline $\begin{array}{l}\text { FEV } 1 . \text { (ATPS) } \\
\text { FVC 1. (ATPS) }\end{array}$ & $\begin{array}{l}\ldots \\
\ldots \\
\ldots \\
\cdots \\
\cdots \\
\cdots \\
\cdots \\
\ldots\end{array}$ & $\begin{array}{c}3 \cdot 40 \\
4 \cdot 33 \\
78 \% \\
6 \cdot 27 \\
2 \cdot 72 \\
1.95 \\
31 \cdot 1 \% \\
30 \cdot 9 \\
85-95 \\
35-45 \\
7 \cdot 35-7 \cdot 45 \\
\text { Negligible }\end{array}$ & $\begin{array}{l}2.04 \\
2.90 \\
70 \% \\
4.94 \\
2.81 \\
1.91 \\
38.7 \% \\
22.6 \\
75.0 \\
32.0 \\
7.50 \\
1500\end{array}$ & $\begin{array}{l}2 \cdot 00 \\
2 \cdot 50 \\
70 \% \\
4 \cdot 00 \\
2 \cdot 7 \\
1 \cdot 3 \\
35 \% \\
14 \\
70 \cdot 0 \\
30 \cdot 0 \\
7 \cdot 5 \\
2500\end{array}$ & $\begin{array}{c}2 \cdot 30 \\
3 \cdot 30 \\
70 \% \\
5 \cdot 25 \\
2 \cdot 79 \\
1 \cdot 72 \\
32 \% \\
29 \cdot 0 \\
78 \cdot 0 \\
42 \cdot 5 \\
7 \cdot 44 \\
50\end{array}$ \\
\hline
\end{tabular}

and throat lesions had healed he was able to take a normal diet and made a satisfactory recovery.

As is usual with paraquat poisoning, hepatic and renal function were impaired. Hepatic damage became evident clinically and biochemically on the fourth day but did not persist (Table I). Renal function was fairly severely impaired, and creatinine clearance, which was as low as $49 \mathrm{ml} / \mathrm{min}$ two weeks after the poisoning, was still only $79 \mathrm{ml} / \mathrm{min}$ after three weeks. At review six weeks later, his blood urea was $41 \mathrm{mg}$ / $100 \mathrm{ml}$ (Table I). The hypokalaemia detected on August 5 was most likely the result of intravenous fluid therapy without adequate potassium replacement and was quickly remedied by the addition of potassium to the intravenous fluid.

Pulmonary dysfunction occurred at an unusually early stage in this man's illness and was evident from the second day after ingestion of paraquat. Table II shows the results of pulmonary function tests and also sputum volumes. The forced expiratory volume in one second $\left(\mathrm{FEV}_{1}\right)$, forced vital capacity (FVC), total lung capacity (TLC), and carbon monoxide transfer factor (TLCO) became significantly reduced and the arterial oxygen and carbon dioxide pressures $\left(\mathrm{PaO}_{2}\right.$ and $\left.\mathrm{PaCO}_{2}\right)$ were also abnormally low. Function returned towards normal with clinical recovery. The chest radiographs showed fine granular opacities in the mid and lower zones and basal plate atelectases. Radiographic changes persisted longer than clinical signs.

At his final out-patient review three months after admission, no clinical or radiographic abnormality was detected in the lungs.

\section{DISCUSSION}

Survival from paraquat poisoning is well documented and has occurred principally in individuals who have ingested or absorbed small amounts of the domestic form of the herbicide Weedol, which contains less paraquat than the commercial preparation Gramoxone (Leading article, 1967; Mourin, 1967; Espir et al., 1970). Skin contact may cause burns, from which paraquat is then absorbed, eye injuries have occurred from splash accidents, and chronic nail-plate damage in agricultural workers handling the substance is recorded (Samman and Johnston, 1969). 
Isolated cranial nerve lesions may also occur (Mourin, 1967) in non-fatal cases of poisoning where very small quantities have been absorbed.

Paraquat is poorly absorbed from the gut and is excreted from the kidney. If the dose is large enough, a fairly characteristic sequence of events ensues (Masterson, 1970). There is mucosal damage to the tongue, mouth, pharynx, and oesophagus within 24 to 48 hours of ingestion, and diarrhoea frequently follows. Acute livercell failure may then occur accompanied by renal failure with heavy albuminuria, nitrogen retention, and severe glomerular damage manifested by a falling creatinine clearance. At this stage, a significant proportion of patients die (leading article, 1967). If renal and hepatic damage do not progress, however, there is a falsely misleading period of 'improvement' of four to six days followed by deterioration with respiratory failure starting usually about 9 to 12 days after poisoning (Bullivant, 1966). McDonagh and Martin (1970) state that 'If a certain concentration of paraquat is reached in the lungs for a short time an irreversible process is initiated'. Matthew et al. (1968) have also stated that when clinical evidence of lung involvement is found in paraquat poisoning, the progression of the pathological events is relentless. In those recorded cases where paraquat was swallowed and the patient survived, either spontaneously or following treatment by forced diuresis, no clinical evidence of lung damage was present at any stage. It is not clear from the literature what dose of paraquat will cause the characteristically delayed damage to the lungs but it has been described as a 'hit and run poison' (Clark, McElligott, and Hurst, 1966), which produces lesions in the lung at a time when paraquat is no longer detectable in the blood or urine. In the present case the concentrated commercial form of the poison was swallowed and forced diuresis was delayed well after the event. Only very small quantities of paraquat were present in the urine before and after forced diuresis. First, there was ulceration of the mouth, dysphagia due to oesophageal damage, and diarrhoea, and then the liver and kidneys were affected, but clinical and radiographic evidence of lung involvement occurred at an earlier stage than is usual. Pulmonary function was impaired on the second day and, by the fourth day after poisoning the patient had become breathless and cyanosed and was coughing up very large quantities of pulmonary oedema fluid. Recovery followed after about 10 days.

Large doses of oral corticosteroids were used on the purely empirical basis of diminishing the inflammatory response of affected tissues. However, this type of therapy was not helpful in other cases dying of respiratory failure (Matthew et al., 1968 ; McDonagh and Martin, 1970) and its value must remain open to doubt.

In experimental animals and in man poisoned by paraquat, histopathology of the lung shows so-called proliferative alveolitis and terminal bronchiolitis (Clark et al., 1966 ; Bullivant, 1966) However, the histopathology in this condition is not uniform. Some areas show emphysematous destruction of the gas exchanging tissues with loss of alveolar walls and over-distended alveoli and terminal bronchioles. Other areas are atelectatic and haemorrhagic and microscopically resemble degassed lungs or those in which surfactant has been destroyed (Matthew et al., 1968 ; Manktelow, 1968). Hyaline membranes are found and fibrosis of large areas of lungs with 'plump' fibroblasts may represent an effort at repair, as may the so-called proliferative alveolitis and bronchiolitis. Thickening of some alveolar walls occurs and bronchiolar epithelium overgrows and may penetrate into the alveoli.

It has been suggested (Manktelow, 1968) that paraquat damages the alveolar cells which manufacture surfactant. Destruction of surfactant might be expected to lead to transudation into the alveoli, causing pulmonary oedema, collapse of fine airways leading to air trapping in some alveoli, and damage to others resulting in emphysema. Uniform inactivation might be expected to cause rapid respiratory failure and death. With the lesions randomly distributed, however, processes of repair known to occur in long-standing damage to the lung, including fibrosis and proliferation of the epithelium, have been seen in some cases. The lungs of animals poisoned with paraquat show loss of surfactant in alveoli and small airways and the presence of the complex in large airways where it does not occur naturally and to which it has presumably been cleared by ciliary activity from damaged alveoli and bronchioles (Manktelow, 1968). Further support for the theory that paraquat poisoning causes destruction of surfactant or impairment of its synthesis comes from experiments in which rats were injected with the substance. Cambar and Aviado (1970) found that, following paraquat injection, the rat lungs became congested. When compared with living control animals there was a decrease in pulmonary compliance and an increase in pulmonary resistance. The excised lungs of paraquat-poisoned rats, when 
compared with those of control rats, had increased total lung water and decreased surfactant activity.

Pulmonary function tests in this patient (Table II) were in keeping with a lesion at the level of gas-exchanging tissues. There was reduction of lung volume and the lost volume was in the vital capacity range. There was no air trapping, as would be evident by increased functional residual capacity (FRC) and residual volume (RV). The TLCo was markedly reduced and blood gases were shifted in a direction seen in syndromes associated with stiff lungs and overbreathing. The patient produced very large volumes of pulmonary oedema fluid, and physical and radiological signs suggestive of this being present were found. The course was not remorseless in this instance, however, and pulmonary function returned towards normal as the production of pulmonary oedema fluid diminished.

It is suggested that this patient ingested a dose of paraquat too small to cause widespread irreversible organ system damage. Some of his symptoms and clinical signs and disordered function tests were compatible with the effects which would follow surfactant destruction. It is also clear that the lungs are capable of recovering from this insult.

I wish to thank Dr. Ian Gordon and Dr. David Proctor for permission to describe this case and Dr. Gordon for encouragement and helpful criticism.

\section{REFERENCES}

Bullivant, C. M. (1966). Accidental poisoning by paraquat: report of two cases in man. Brit. med.J., 1, 1272.

Cambar, P. J., and Aviado, D. M. (1970). Bronchopulmonary effects of paraquat and expectorants. Arch. environm. Hlth, 20, 488.

Clark, D. G., McElligott, T. F., and Hurst, E. W. (1966). The toxicity of paraquat. Brit. J. industr. Med., 23, 126.

Espir, M. L., Hall, J. W., Shirreffs, J. G., and Stevens, D. L. (1970). Impotence in farm workers using toxic chemicals. Brit. med. J., 1, 423.

Kerr, F., Patel, A. R., Scott, P. D. R., and Tompsett, S. L. (1968). Paraquat poisoning treated by forced diuresis. Brit. med. J., 3, 290.

Leading article (1967). Poisoning from paraquat. Brit. med. J., 3, 690.

Manktelow, B. W. (1968). The loss of pulmonary surfactant in paraquat poisoning. Brit.J. exp. Path., 48, 366.

Masterson, J. G. (1970). Fatal paraquat poisoning. J. Irish med. Ass., 63, 261.

Matthew, H., Logan, A., Woodruffe, M., and Heard, B. (1968). Paraquat poisoning-lung transplantation. Brit. med. J., 3, 759.

McDonagh, B. J., and Martin, J. (1970). Paraquat poisoning in children. Arch. Dis. Childh., 45, 425.

McKean, W. I. (1968). Recovery from paraquat poisoning. Brit. med. J., 3, 292.

Mourin, K. A. (1967). Paraquat poisoning. Brit. med. J., 4, 486.

Oreopoulos, D. G., and McEvoy, J. (1969). Diquat poisoning. Postgrad. med.J., 45, 635.

Samman, P. D., and Johnston, E. N. M. (1969). Nail damage associated with the handling of paraquat and diquat. Brit. med.J., 1, 818. 